\title{
Psychological empowerment as a predictor of quality in training - a glance at the Portuguese context
}

\author{
Isabel Gomes (1), Joaquim Luís Coimbra (2) \& Isabel Menezes (3)
}

(1) isabelgomes@fpce.up.pt

(2) jcoimbra@fpce.up.pt

(3) imenezes@fpce.up.pt

Faculty of Psychology and Education - University of Porto

Rua do Campo Alegre, 1021/1055

4169-004 Porto

Portugal

\begin{abstract}
:
This paper analyses the model of Adult Education and Training (AET) in Portugal, taking under consideration the two available reports on this recent domain, which reveal that empowerment is a prescriptive goal. However, this construct continues to be ill defined.

The empowerment theory suggested by Zimmerman and colleagues, particularly the psychological empowerment construct, shows enough consistency with the AET model to consider that it might contribute to the management of quality in training.

These reports also state the urge for better, more inclusive and more reliable measures in assessing quality in training. Contributions of the empowerment theory to this matter are discussed, attempting to analyse and operacionalize it in this specific domain.
\end{abstract}

Key-words: Empowerment - Psychological Empowerment - Adult Education and Training Assessment - Quality in training. 


\title{
Psychological Empowerment as a predictor of quality in training - a glance at the Portuguese context
}

\begin{abstract}
This paper analyses the model of Adult Education and Training (AET) in Portugal, taking under consideration the two available reports on this recent domain, which reveal that empowerment is a prescriptive goal. However, this construct continues to be ill-defined.

The empowerment theory suggested by Zimmerman and colleagues, particularly the psychological empowerment construct, shows enough consistency with the AET model to consider that it might contribute to the management of quality in training.

These reports also state the urge for better, more inclusive and more reliable measures in assessing quality in training. Contributions of the empowerment theory to this matter are discussed, attempting to analyse and operacionalize it in this specific domain.
\end{abstract}

\section{The Adult Education and Training model and its practice(s) - Portugal}

European countries have definitely came to realise the importance of lifelong learning as a nuclear issue on social and economical development, «Making lifelong learning a reality for all lies at the heart of the Lisbon strategy for making Europe a prosperous and rewarding place to live and work in the 21st century world.»(CEDEFOP, 2003). Other important political documents also recognise the growing importance of qualifications and competencies in the actual developing contexts. For instance, the UNESCO report (co-ordinated by Jacques Delors ${ }^{11}$ ) refers to the issues of lifelong learning, learning societies and articulation between initial education and continuing education; on the other hand, the Lifelong Learning Memorandum (European Commission, 2000²), states that Lifelong Learning should consider the following dimensions:

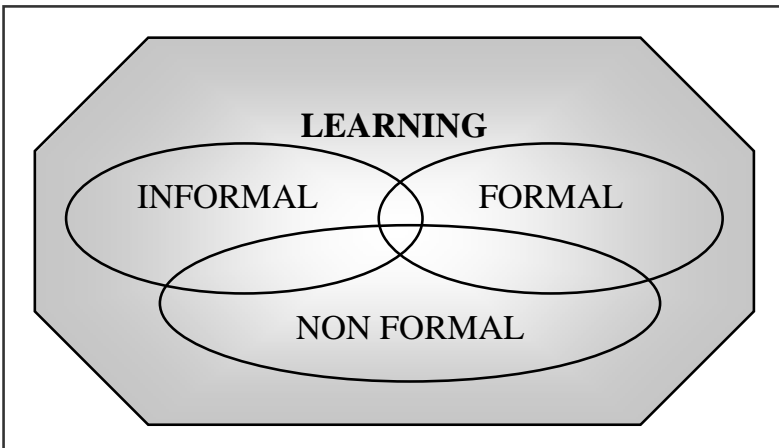

Figure 1 - Dimensions of learning 
Based on this general perspective, the Adult Education and Training (AET) model has recently been put into practice in Portugal, aiming to organise interventions that «focus on social justice and wish to promote equal opportunities and participative citizenship». (Canelas, 2002: 11). These goals can only be achieved through very specific and original training characteristics, "in a perspective of construction of new social relations, interactive and empowering, able to provide those adults the opportunity to build their own personal and professional projects." (ibid.: 12). First and foremost, AET's philosophical and epistemological arguments rely on the notion of competencies (general, vocational and keycompetencies). Based on this, the essential "prescriptive" documents that regulate training are the Key-Competencies Framework, which leads to a process of Recognition and Validation of Prior Learning (RVPL) and the Vocational Training Framework, both articulated in the same process.

Training begins with an initial process of gathering and exploration of self-reports and evidences that result from learning in various contexts, where the participant recognises and validates his/her lifelong learning, followed by individual training, (re)constructed around the participant's needs. The specific structure of these courses is shown in Table 1:

\begin{tabular}{|c|c|c|c|c|c|}
\hline \multirow{2}{*}{$\begin{array}{c}\text { Training } \\
\text { options }\end{array}$} & \multirow{2}{*}{ RVPL } & $\begin{array}{c}\text { Learning } \\
\text { with } \\
\text { Autonomy }\end{array}$ & $\begin{array}{c}\text { Key- } \\
\text { Competencies } \\
\text { Areas }\end{array}$ & $\begin{array}{c}\text { Vocational } \\
\text { Training }\end{array}$ & Total (hours) \\
\hline Basic 1 & $25 \mathrm{~h} / 40 \mathrm{~h}$ & $40 \mathrm{~h}$ & $100 \mathrm{~h} / 400 \mathrm{~h}$ & $220 \mathrm{~h} / 360 \mathrm{~h}$ & $385 \mathrm{~h} / 840 \mathrm{~h}$ \\
\hline Basic 2 & $25 \mathrm{~h} / 40 \mathrm{~h}$ & $40 \mathrm{~h}$ & $100 \mathrm{~h} / 400 \mathrm{~h}$ & $220 \mathrm{~h} / 360 \mathrm{~h}$ & $385 \mathrm{~h} / 840 \mathrm{~h}$ \\
\hline Basic $1+2$ & $25 \mathrm{~h} / 40 \mathrm{~h}$ & $40 \mathrm{~h}$ & $100 \mathrm{~h} / 800 \mathrm{~h}$ & $220 \mathrm{~h} / 360 \mathrm{~h}$ & $385 \mathrm{~h} / 1240 \mathrm{~h}$ \\
\hline Basic 3 & $25 \mathrm{~h} / 40 \mathrm{~h}$ & $40 \mathrm{~h}$ & $100 \mathrm{~h} / 800 \mathrm{~h}$ & $940 \mathrm{~h} / 1200 \mathrm{~h}$ & $1105 \mathrm{~h} / 2080 \mathrm{~h}$ \\
\hline Basic 2+3 & $25 \mathrm{~h} / 40 \mathrm{~h}$ & $40 \mathrm{~h}$ & $100 \mathrm{~h} / 1200 \mathrm{~h}$ & $940 \mathrm{~h} / 1200 \mathrm{~h}$ & $1105 \mathrm{~h} / 2480 \mathrm{~h}$ \\
\hline \multicolumn{7}{|c}{} \\
Transversal area in the curriculum which themes, selected from the interaction between local \\
and global worlds, inform and organise the approach in the different key-competencies areas.
\end{tabular}

In this training structure, there is a prominent figure, the mediator, who's present from the beginning till the end of the training process, accompanying trainees and trainers, articulating

\footnotetext{
${ }^{3} C f$. Canelas (2002: 19). Basic 1 refers to the 4th year of academic certification/ Level I of vocational qualification; Basic 2 to the 6th year of academic certification/Level II of vocational qualification; Basic 3 to the 9 th year of academic certification/Level II of vocational qualification.
} 
resources and community organisations as well as giving feed-back to the promoting entities. This leads to another important feature in the AET processes, which is the centrality of the pedagogical team, responsible for the complex task of putting into practice the concepts of such a compound training system.

Another specificity of AET is related to the process of assessment in AET courses, as referred in Figure 2.

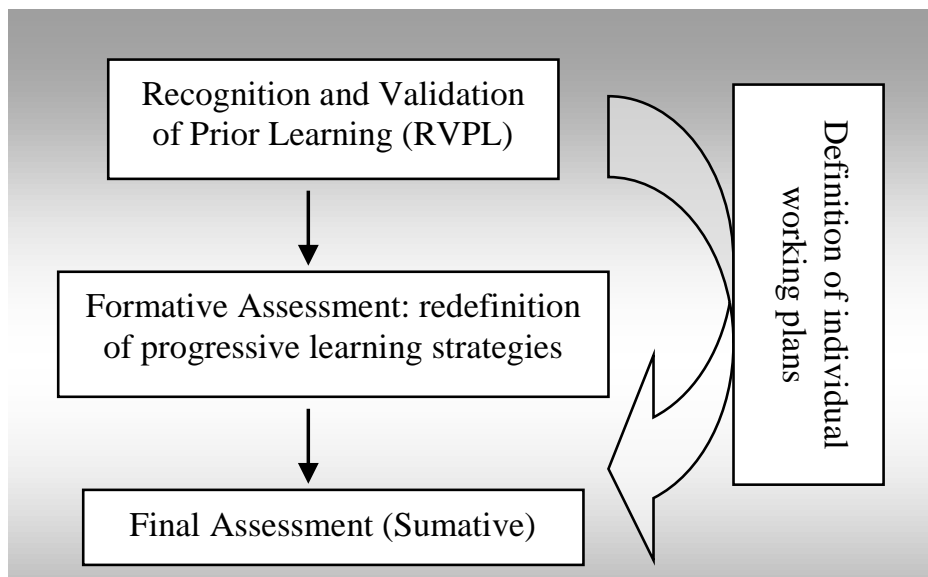

Figure 2 - Trainee's assessment in AET Courses

One final aspect of AET is the particular importance given to the community in which the training takes place - whether building learning relationships, trading know-how and experience with relevant organisations in the community, or the impact of having more qualified, participative and critical individuals in the community. The AET model aims to evolve people, entities and the larger community, taking into account their very own specificity. In a way, we could say that AET could create "settings that promote communal and personal stories and [permit to] listen more carefully to the voices telling those stories" (Perkins \& Zimmerman, 1995: 571), therefore constituting an empowering intervention.

\section{Assessing practice(s) - The reports on AET}

The two available reports on the AET training that took place in Portugal, between the years 2000 and 2003 (Canelas, 2002; Canelas, 2004), essentially show qualitative data such as the regional characteristics of the AET courses' Portuguese offer, the profile of the pedagogical team, the RVPL process and the curricular construction, assessing the opinions of different actors through questionnaires and regional reports. The representativeness of the sample wasn't an issue, since the objective of these questionnaires was to "draw the AET's universe" (Canelas, 2004: 34). The total number of respondents taken into analysis (trainers, mediators, trainees and promoting entities) was about 4595 (ibid.). 
Results show that interventions based on this model are growing in number and in importance. One of the findings shows the particular social characteristics of the participants in the AET courses: adults from disenfranchised groups (particularly those benefiting from state minimum income) and unemployed active adults (ibid.: 38), thus urging for the reflection on adapted methodologies for these populations. One other result indicates that women are more represented than men (about 80\%, concentrating on the ages of 25-34) (ibid.: 39), suggesting that the first are more available to take these qualification opportunities.

As far as the curriculum is concerned, the "Life Themes" area was considered the most effective, becoming the most participative "place", as reported by trainees, contributing to their involvement and interest in training, while collectively deciding local relevant themes to work. We can also observe that all aspects referring to the curricular planning and development tend to generate trainees' participation, independently of the area concerned (ibid.: 91).

Results show that the RVPL process is considered as a very positive experience, characterised by the specificity of occurring mostly in individual sessions, which gives trainees the opportunity to assume responsibilities and feel motivated towards the learning process (ibid.). However, the major difficulties reported by the respondents were in articulating the results of the RVPL process and the "General Training", due to the novelty and complexity of the training model. This also happened in the evaluation of the "Learning with Autonomy" classes.

"Vocational Training" is considered a major strength of the training process and it's the participants preferred area (namely to the younger participants in the B3 option), probably because it's where the trainees have real contact with working experiences, as stated in the reports (ibid:: 104).

Finally, the results documented in both reports undoubtedly indicate that «the social value of this initiative [is that] adults (...) reveal, in the opinion of mediators and trainers, a strong involvement and interest in the whole process.» (ibid.:128).

\section{Empowerment Theory}

Empowerment has special relevance in adult low-qualified populations, «frequently at risk of social exclusion» (Canelas, 2002: 12) and in the development of new methodologies that can be adaptive and effective in this particular group of people, whether we refer to the European 
context(es) or to the Portuguese particular setting(s). Research concerning the empowerment construct (Foster-Fishman et al., 1998; Perkins \& Zimmerman, 1995; Zimmerman et al., 1992; Zimmerman \& Warschausky, 1998; Zimmerman, 1995; Zimmerman, 2000; Zimmerman \& Zahniser, 1991) has demonstrated that it is multidimensional, depends a great deal on the individual and the context, and varies across time.

This theory has been contributing significantly to the understanding and operationalization of this yet ill-defined construct. One of the first issues that the nomological network of empowerment addresses is the distinction between empowerment values (that theoretically support the programmes), empowering processes (designed to promote opportunities of empowerment development) and empowered outcomes (as result of empowering processes), which we explain in Figure 3:

\begin{tabular}{|c|c|c|}
\hline $\begin{array}{l}\text { EMPOWERMENT } \\
\text { VALUES: } \\
\text { Concerned with issues } \\
\text { like health, adaptation, } \\
\text { competencies and natural } \\
\text { helping systems, } \\
\text { implying a relationship } \\
\text { between professional and } \\
\text { trainer in which the first } \\
\text { becomes, himself, an } \\
\text { empowering element. }\end{array}$ & $\begin{array}{l}\text { EMPOWERING } \\
\text { PROCESSES: } \\
\text { Mechanisms that lead } \\
\text { individuals, organisations } \\
\text { and communities to gain } \\
\text { mastery over issues that } \\
\text { concern them, develop } \\
\text { critical awareness about } \\
\text { their socio-political } \\
\text { environment and } \\
\text { participate in decisions } \\
\text { that affect their lives. }\end{array}$ & $\begin{array}{l}\text { EMPOWERMENT } \\
\text { RESULTS: } \\
\text { Consequences of } \\
\text { empowering processes, } \\
\text { relating to the } \\
\text { psychometric measures } \\
\text { that assess the } \\
\text { interventions' results (at } \\
\text { different levels of } \\
\text { analysis). }\end{array}$ \\
\hline
\end{tabular}

Figure 3 - Contributions of the empowerment theory

Zimmerman's theory (e.g., Perkins \& Zimmerman, 1995; Zimmerman, 1995; Zimmerman, 2000) postulates that empowerment differs across three levels of analysis, as shown in Figure

4.

Individual Level:

Personal perceptions of control, critical awareness of the factors that guide personal efforts to exert control over one's life and participation with others in order to achieve goals.

\author{
Organisational \\ Level: \\ Processes that \\ enhance \\ members' \\ participation and \\ improve \\ organisational \\ efficacy.
}

\section{Community Level: \\ Collective action in order to improve life quality in a community and the relation between different community organisations and entities.}


We can observe that «participation or provision of opportunities to participate are common themes across each level.» (Zimmerman \& Warschausky, 1998: 6). On the other hand, it is suggested that empowerment is related to three different dimensions: participation, critical awareness and control, within each of the three levels of analysis (Zimmerman \& Zahniser, 1991; Zimmerman, 2000).

Finally, the theoretical model of psychological empowerment (Zimmerman et al., 1992; Zimmerman, 1995; Zimmerman, 2000), as a dimension of the individual level of analysis, postulates three components - intrapersonal, interactional and behavioral, which composition we can observe in Figure 5:

$\begin{array}{ll}\begin{array}{l}\text { Intrapersonal } \\ \text { component : }\end{array} & \begin{array}{l}\text { Interactional component: } \\ \text { Perception of the relationship }\end{array} \\ \text { Self-perception about } & \text { between individual and social } \\ \text { control (personal, } & \text { environment, namely the } \\ \text { interpersonal and } & \text { critical awareness of available } \\ \text { socio-political), self- } & \text { resources in the context that } \\ \text { efficacy, motivation to } & \text { help achieving goals, problem } \\ \text { control, perceived } & \text { resolution and decision } \\ \text { competency and locus } & \text { making skills. } \\ \text { of control. } & \end{array}$

Intrapersonal

Self-perception about control (personal, interpersonal and efficacy, motivation to control, perceived of control.
Interactional component: between individual and social environment, namely the resources resolution and decision
Behavioral component: Specific actions taken by the individual in order to influence the socio-political environment, by participating in community activities.

Figure 5 - Components of the psychological empowerment

We could say that the relevance of psychological empowerment in the context of AET is essentially related to the nuclear position of the trainee as the essential element around which the curriculum and the pedagogical options are built (Canelas, 2002). The participant is seen as someone carrying significant experiences and learning, which cannot be ignored in the training process, thereby bringing into the training the raw material to be explored, developed and formally recognised in the process. This emphasis on the individual that the AET model states to privilege, leads us to assume that psychological empowerment is the most appropriate construct to explore when analysing the impact of this specific training model.

\section{State of the art in evaluating training}

Bonnet (2004:181) argues that "latest developments in th European Union must surely imply that subsidiarity in education is taking on a new meaning", reflecting the emergence of a global worry on human development through training. But, even though training is considered to virtually be the answer to most of our modern problems, the evaluation of these processes is far from answering the big questions: What are the real effects of all this training? What is 
the return of the enormous financial, human and institutional investment uppon which all this training has grown up?

Empirical litterature about assessment in training leads us to some interesting theoretical models like, for instance, Belzer (2004). Using a qualitative approach, she found that “learners' constructions of previous learning contexts function as «screens» between the learner and the learning" (ibid.: 41), which is particularly important when we deal with a population that withdrawed from school for several years, as well as to the reflexion on training assessment. These findings suggest that there are three ways of dealing with the learning context: if the present learning experience is congruent with the previous one, the adult learners feel comfortable; when the first one creates some kind of dissonance, the adults feel uncomfortable and ambivalent about the learning context; finally, when the present learning situation is incongruent with previous experiences: "Here the response is either to stop coming to class or to reconstruct and build new expectations about contexts for learning." (ibid.: 47).

Kirckpatrick's framework (e.g., Warr et al., 1999; Bowers et al., 2003), on the other hand, predicts four levels of outcomes: reactions [to training], i.e., how participants felt about the training; learning, i.e., the actual acquisition of procedural or declarative knowledge, [job] behaviour and results [metrically derived]. Studies based on this model (Warr et al., 1999: 351) have shown that "immediate and delayed learning were predicted by trainees' motivation, confidence and use of certain learning strategies and changes in job behaviour were independently predicted by transfer climate and learning confidence.".

Bonnet (2004: 183), from an european perspective, defines the evaluation of education through indicators that fall into three categories: input, process and outcome (or output). Analysing these dimensions, the author concludes that the recurrent indicators being used in european evaluation of education are economical and descriptive, instead of inlcusive and reflexive, dearing to suggest: "To complement the existing international surveys it is necessary to develop indicators which describe education from other angles, in particular indicators based on studies which take into account the cultural environment and reflect the specific aims of education in Europe". (ibid.: 185).

From this small review, we can conclude that despite the significative amount of theoretical debate, the results of these evaluation models aren't availabe yet. So we could address Rose (1968: 38), in «Everybody talks about training evaluation, but as Mark Twain said about the weather "nobody does much about it."». 


\section{Empowerment and Education}

Despite some attempts to study empowerment empirically,some work has been done on the development of sound measures that try to capture the real expressions of this construct in the education domain. Frymier and Shulman (1994), report a scale adaptation and validation study, in which they composed a "learner empowerment scale". The authors recognised that empowered students were more prepared to undertake challenges and perform with quality, thus facing nowaday's demands. Based on the previous works of Thomas \& Velthouse (1990, In Frymier \& Shulman, 1994), their concept of learner empowerment included the dimensions of impact (perception that actions taken may have an impact on the environment), choice (degree of self-regulation in the management of tasks, methods and strategies), meaningfulness (value of the task in relation to the participants' values, beliefs and ideals) and competence (sense of personal qualification and capability to perform actions in order to achieve goals) . Considering the empowerment as a mediating variable, between exogenous (immediacy behaviours and self-esteem) and endogenous (learning) variables, the results of this study showed that "the intervening empowerment variable was a significant predictor of learning." (ibid.:18). However, the authors alert to the fact that a greater distinction between empowering contexts and empowered students should be made in order to clarify the construct.

The most recent study on the impact of the AET model in adult development comes from Amorim (in press), revealed gains in adults' vocational development and less personal alienation, which might lead us to finally relate to the psychological empowerment construct.

\section{Psychological Empowerment as a predictor of quality in training}

When we talk about quality in training, we refer precisely to the consistency between prescriptive goals and real outcomes, more than to the actors' satisfaction or other descriptive dimensions. In fact, this is what has been missing, both in empowerment theory, as far as empirical studies are concerned (Zimmerman, 1995; Zimmerman, 2000) and in the AET domain, requiring new forms of assessment (Canelas, 2002; Canelas, 2004).

As we can observe, empowerment is a construct consistent with the AET model's values and processes. The reports on which this paper has relied, however, show very few about how these values and processes have actually had an impact on each AET participant, i.e., no psychological empowerment measures have been analysed in the reports. We can admit that some interesting dimensions have been captured like motivation, participation in specific 
activities, preferences, and some articulation between social characteristics like age, sex, social status (derived from the funding of each course) has been made, however, that is not enough, which lead us to elaborate a new research scheme for assessment in AET:

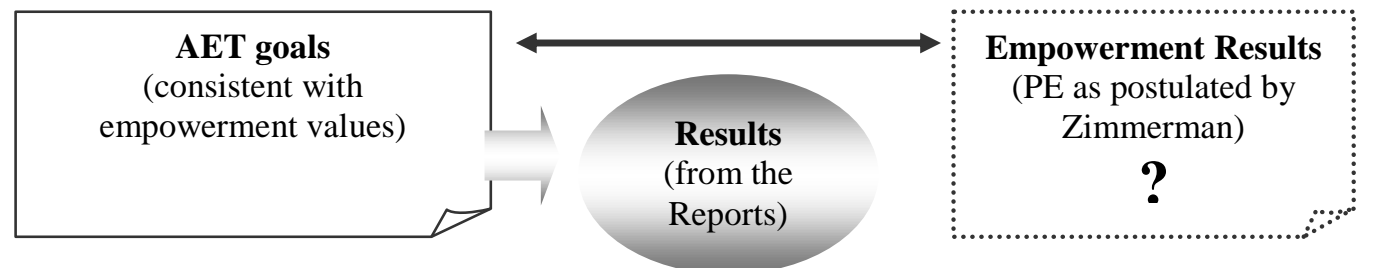

Figure 6 - Proposal for assessment in AET

Reports refer that trainees' "attitudes and (...) behaviours have changed, being more active and exigent, "creating challenge" (...)» (Canelas, 2004: 94), their self-confidence and autonomy have improved (ibid.: 96), as an effect of participating in AET interventions. However, it is also stated that «available elements don't permit the assessment of the concrete effects on reported changes at the level of labour market inclusion. Despite this, these changes (in attitudes and behaviour), along with the acquired resource (academic certification) will undoubtedly contribute to the positive results that might be achieved.» (ibid.: 127).

We observed that the AET model, despite its consistency, in what prescriptive goals are concerned, with Zimmerman's theory of empowerment, lacks further analysis on the articulation between goals, processes and outcomes. We have also observed the difficulties in assessing training programs and defining the most accurate measures to do so. Our project, though predictably difficult, is to develop not only sound measures, but also fundamented reflexions, that can help us answer the questions aroused in this paper.

\section{References}

[1] Belzer, A. «"It's not like normal school”: the role of prior learning contexts in adult learning.», ADULT EDUCATION QUATERLY, vol. 55, No 1, pp. 41-59, 2004.

[2] Amorim, J.P. “A Metamorfose das Borboletas". Tese de Mestrado FPCEUP, Porto, in press.

[3] Bonnet, G. "Evaluation of education in the European Union: policy and methodology", ASSESSMENT IN EDUCATION, vol. 11, No 2, pp. 179-191, 2004.

[4] Bowers, C. L., Hitt II, J. M., Hoeft, R. M. \& Dunn, S. “Applying training evaluation models to the clinical setting”, MILITARY PSYCHOLOGY, vol. 15, No 1, pp. 17-24, 2003. 
[5] Canelas, A. M. "Relatório Nacional - Cursos de Educação e Formação de Adultos "Em Observação" 2000/2001”, ANEFA, Lisboa, 2002.

[6] Canelas, A. M. "Relatório nacional de avaliação: cursos de educação e formação de adultos 2002/2003", DGFV, Lisboa, 2004.

[7] CEDEFOP. "Lifelong learning: citizen's views”, OFFICE FOR OFFICIAL PUBLICATIONS OF THE EUROPEAN COMMUNITIES, Luxembourg, 2003.

[8] Foster-Fishman, P. G., Salem, D. A., Chibnall, S., Legler, R. \& Yapchai, C. "Empirical support for the critical assumptions of empowerment theory”. AMERICAN JOURNAL OF COMMUNITY PSYCHOLOGY, vol. 26, No 4, pp. 507-536, 1998.

[9] Frymier, A. B. \& Shulman, G. M. "Development and testing of the learner empowerment instrument in a communication based model", Paper presented at the Annual Meeting of the Speech Communication Association (80 ${ }^{\text {th }}$, New Orleans, LA, November 19-22, 1994).

[10] Perkins, D. D. \& Zimmerman, M. A. "Empowerment theory, research and practice”, AMERICAN JOURNAL OF COMMUNITY PSYCHOLOGY, vol. 23, No 5, pp. 569-579, 1995.

[11] Rose, H. C. “A plan for training evaluation", TRAINING AND DEVELOPMENT JOURNAL, pp. 38-51, 1968.

[12] Warr, P., Allan, C. \& Birdi, K. "Predicting three levels of training outcome", JOURNAL OF OCCUPATIONAL AND ORGANIZATIONAL PSYCHOLOGY, vol. 72, pp. 351-375, 1999.

[13] Zimmerman. M. A. "Psychological empowerment: Issues and illustrations", AMERICAN JOURNAL OF COMMUNITY PSYCHOLOGY, vol. 23, No 5, pp. 581-599, 1995.

[14] Zimmerman, M. A. "Empowerment theory. Psychological, organizational and community levels of analysis", In J. Rappaport \& E. Seidman (Eds.), "Handbook of Community Psychology", KLUWER ACADEMIC/PLENUM PUBLISHERS, pp. 43-63, New York, 2000.

[15] Zimmerman, M. A, Israel, B A., Schulz, A \& Checkoway, B. "Further explorations in empowerment theory: an empirical analysis of psychological empowerment”, AMERICAN JOURNAL OF COMMUNITY PSYCHOLOGY, vol.20, No 6, pp. 707-727, 1992.

[16] Zimmerman, M., A \& Warschausky, S. "Empowerment theory for rehabilitation research: conceptual and methodological issues", REHABILITATION PSYCHOLOGY, vol. 43, No 1, pp. 3-16, 1998. 
[17] Zimmerman, M. A, \& Zahniser, J. H. "Refinements of sphere-specific measures of perceived control: development of a sociopolitical control scale", JOURNAL OF COMMUNITY PSYCHOLOGY, vol. 19, pp. 189-204, 1991. 